\title{
準モノサイクルパルスと二重光学ゲート法を用いた 超広帯域アト秒コンティニューム発生
}

\author{
小栗 克弥, 増子 拓紀, 後藤 秀樹 \\ 日本電信電話 (株) NTT物性科学基礎研究所 ( ⿳亠丷厂 243-0198 神奈川県厚木市森の里若宮3-1)
}

\section{Generation of Isolated Attosecond Continua with over $70 \mathrm{eV}$ Bandwidth by Using Doubly Optical Gated Sub-Two-Cycle Pulse}

\author{
Katsuya OGURI, Hiroki MASHIKO, and Hideki GOTOH \\ NTT Basic Research Laboratories, Nippon Telegraph and Telephone Corporation, \\ 3-1 Wakamiya, Morinosato, Atsugi-shi, Kanagawa 243-0198
}

(Received March 13, 2017)

\begin{abstract}
The generation of an isolated attosecond pulse (IAP) has been pioneering new breakthroughs in the field of ultrafast science since the first measurement in 2001. Here, we review the recent technological advances in the IAP generation from the view point of ultrabroadband attosecond continua, which support sub-50-as pulse generation. We also introduce our studies for the IAP generation based on a high-intensity Ti:sapphire laser system. In particular, we report the generation of the attosecond supercontinuum spectrum with an extremely broad bandwidth of $70 \mathrm{eV}$ at full width half maximum, which suggests the generation of 32-as pulse, based on the combination of the amplitude gating and the double optical gating schemes using the driving laser field with sub-two-cycle duration. Our approach will be a promising method for generating the shorter IAP that achieves an improved temporal resolution for investigating electron dynamics in unprecedented attosecond timescale.
\end{abstract}

Key Words: Attosecond pulse, Double optical gating, Monocycle pulse, High-order harmonics

\section{1.はじめに}

2001年に, 初めてアト秒領域の時間幅を持つ光パルス (アト秒パルス)が, 確認されて以来 ${ }^{1)}$, アト秒時間領域 の光技術及び電子ダイナミクスを追求する「アト秒科学」 は，量子エレクトロニクス分野の新しい潮流として，各 国で研究が進められている. その原動力の一つは, 単一 アト秒パルス発生技術の著しい進展であることは言を俟 たない、単一アト秒パルスと, ポンプ・プローブ法を組 み合わせた「アト秒時間分解分光法」は, 最も直接的なア ト秒ダイナミクスの計測手法であるため，原子 ${ }^{2)}$ ，分 子 $^{3)}$, 固体 ${ }^{4)}$, 表面 ${ }^{5)}$, 生体関連物質 ${ }^{6)}$ など様々な系に適 用されてきた。 今後, 数年のうちに, 物質科学の専門家 らがユーザとして利用する超高速時間分解分光ツールと

して確立していくことになるだろう。

現在, 単一アト秒パルスの発生技術は, パルス幅 が50 asに迫りつつあると共に7,8)，波長も300 eVを超え るような軟X線領域に突入している ${ }^{9-11)}$ 。そのパルス強 度はGWレベルに到達し ${ }^{12,13)}$, MHzレベルの繰返し周波 数を有するアト秒パルス発生も報告されている ${ }^{14)}$.この ように単一アト秒パルス光源は，各国で研究開発がます
ます加速している ${ }^{15,16)}$ ，そこで，本稿では，現在実証さ れているいくつかの有望な単一アト秒パルス発生のス キームについて解説するとともに, 我々のグループで実 現している単一アト秒パルス発生について紹介したい.

\section{2. 単一アト秒パルスの発生法}

アト秒パルス発生は, 高強度フェムト秒レーザーパル スを希ガス原子中に集光することで発生する高次高調波 発生 (High-order Harmonic Generation: HHG) の一形態で あることはよく知られている ${ }^{17-19)}$. HHGのメカニズム は, 高強度フェムト秒レーザーパルス (基本波)と原子中 の最外殼電子との相互作用を記述する3ステップ(再衝 突) モデルによって直観的に理解することが可能であ る ${ }^{20,21)}$. それは, (i)電子のトンネルイオン化, (ii) 束縛 状態を離れた自由電子のレーザー電界による運動, （iii） 自由電子の親イオンとの放射再結合化の3つのステップ から成る。この一連の過程は，基本波の半周期毎に正確 に繰り返されるため, 高次高調波は, アト秒パルスが基 本波の半周期毎に放射されるアト秒パルス列と見なすこ とができる，従って，単一アト秒パルスの発生は，この 
アト秒パルス列から，1本だけ取り出すことによって実 現できる. 問題は, わずか $1 \mathrm{fs}$ 程度しかない半周期の間 にアト秒パルスの発生をどのようにオン・オフ(スイッ チング)するかという点である。このアト秒スイッチン グの方法によって, 単一アト秒パルスの発生は, 以下の 四つに分類することができる。

1 番目は, 数周期の電界しか含まない短パルス(数サイ クルパルス)でアト秒パルスを発生させ，隣り合うピー ク電界の振幅の違いをスイッチとして利用する方法であ る(振幅ゲート法 $)^{8,22,23)}$. 基本波パルスとその二倍波パ ルスを重ねあわせることによって, 隣り合うピーク電界 の振幅のコントラストを上げることでスイッチングの切 れを良くする二色ゲート法や ${ }^{24)}$, 多色パルスのフーリエ 合成波を用いる方法 ${ }^{12,25,26)}$ なども基本的にこのカテゴ リーに分類される，2番目は，高次高調波が原理的に直 線偏光の基本波で最も効率良く発生することをスイッチ として利用する方法である(偏光ゲート法 ${ }^{27,28)}$. 互いに 逆回転する円偏光を基本波とし，重ね合わせることに よって，基本波の楕円率を時間的にスイッチングする。 これにより一周期程度の時間領域にだけ直線偏光の部分 を作りだし、アト秒パルスの発生を基本波の一周期程度 のみに限定することができる，偏光ゲート法に二色ゲー 卜法を組み合わせた二重光学ゲート (Double Optical Gate: DOG) 法は，二倍波を重ねあわせることによって直線偏 光部分を半周期程度でスイッチングできる方法であ る る $^{2903)}$. 3番目は, トンネルイオン化の高い非線形性を スイッチとして利用する方法である(イオン化ゲート

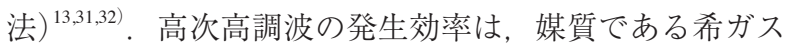
中性原子の密度に依存するため, サブサイクル時間の立 ち上がりでイオン化させることによって中性原子数密度 を瞬時に枯渇させ，アト秒パルス列発生を強制的に遮断 する方法である。最後は，比較的最近実証された高次高 調波発生の時空間結合を利用する方法である(時空間 ゲート法 $)^{33,34)}$ 。これは，基本波に空間チャープを与え ることにより，焦点位置で波面が時間的に回転するビー ムを作り出し, 波面の回転をスイッチとして利用するこ とによって, 半周期毎に発生するアト秒パルス列の発光 時間を伝搬角へ写像する方法である。この効果は, “ア 卜秒灯台 (attosecond lighthouse)”と呼ばれており, 単一 アト秒パルスを空間的に分離することが可能である

単一アト秒パルスを特徴づける最も重要な指標は言う までもなくパルス幅である。最短アト秒パルス発生とい う軸で見ると，50 asを切るような単一サブ50 asパルス の発生と計測に競争のステージが移っている。サ ブ50 asのパルス幅を実現するスペクトルの帯域幅 は，100 eV近くにまで達する。そのような超広帯域のア 卜秒パルスを発生するためには, カットオフエネルギー を100 eVを超えるような高エネルギー領域にまで拡大し て，スペクトルの超広帯域化することが最も直接的であ る. カットオフエネルギーは基本波のピーク強度と波長 の二乗に比例するため, カットオフエネルギーの拡大に は, ピーク強度を増強するか, 波長を短波長化させる必 要がある。最近では, 赤外領域の超短パルスを基本波と
する，短波長領域の超広帯域連続スペクトル(コンティ ニューム)の発生実験が行われている ${ }^{9-11)}$. 基本波パルス の長波長化は, 現状, 光パラメトリック増幅器 (Optical Parametric Amplifier: OPA) や光パラメトリックチャープ パルス増幅器 (Optical Parametric Chirped-Pulse Amplifier: OPCPA)が用いられている.

一方, 我々は, チタンサファイアレーザーと中空ファ イバ圧縮器を用いたシステムによって, 単一アト秒パル ス発生の研究を進めている。本稿では，我々がこれまで 進めてきた単一アト秒パルス発生の研究について紹介す る。特に，最近実現した $800 \mathrm{~nm}$ 帯の準モノサイクルパ ルスと二重光学ゲート法との組合わせによる半值全 幅70 eVに達するような超広帯域コンティニューム発生 について解説する，超広帯域コンティニュームのスペク トル全域に渡るキャリアエンベロープ位相 (Carrier Envelope Phase: CEP) 依存性を計測することにより，フーリ エ変換限界パルスを仮定した場合，およそ30 asの単一 アト秒パルスを発生可能であることを示した.

\section{3. 振幅ゲート法によるアト秒パルス発生}

本章では，数サイクルパルス（３周期程度）を用いた 振幅ゲート法による単一アト秒パルス発生を紹介する。 Fig. 1 (a) は，CEP安定化無しのスペクトルであり，カッ
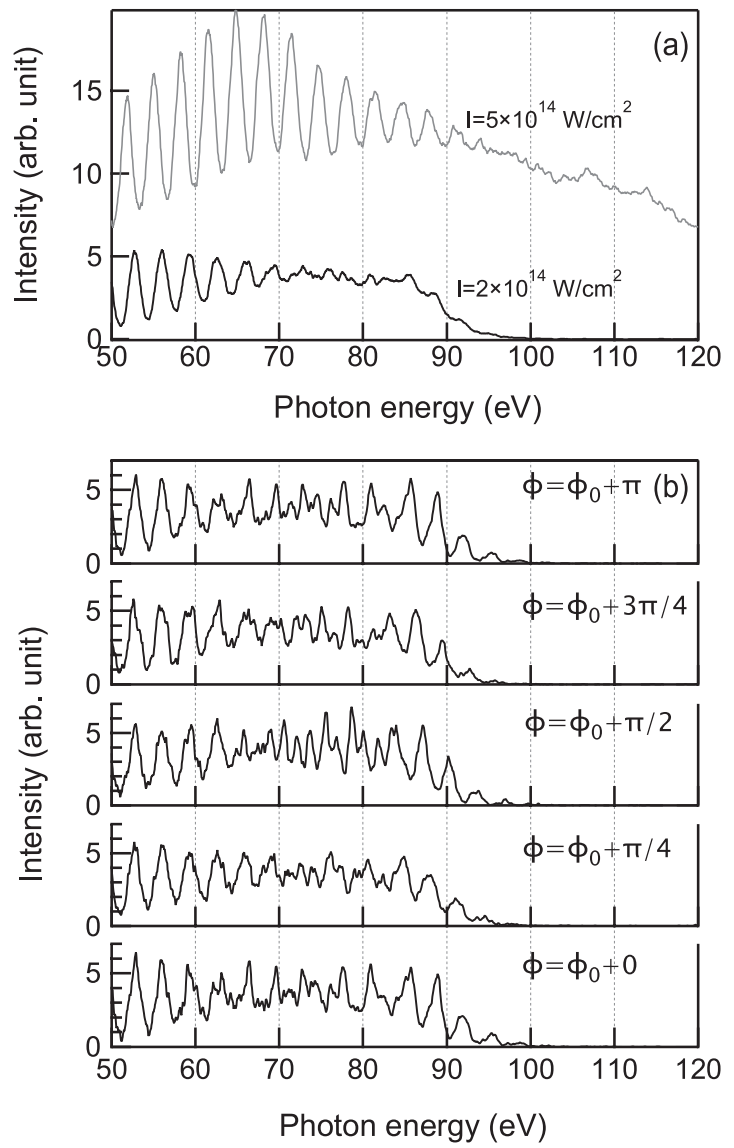

Fig. 1 High-harmonic spectra from 50 to $120 \mathrm{eV}$ obtained at different peak intensities without CEP stabilization (a). CEP dependence of the harmonic spectrum at $2 \times 10^{14} \mathrm{~W} / \mathrm{cm}^{2}(\mathrm{~b})$. 
トオフ領域が一見コンティニューム化しているように見 える.これは, 様々なCEPの時のアト秒パルスのスペク トルが重ね合わさった結果であり，CEPを安定化すると 櫛状スペクトル構造が現れる。 Fig. 1 (b) は，CEPを安定 化したパルス幅6-7 fs 程度, ピーク強度 $2 \times 10^{14} \mathrm{~W} / \mathrm{cm}^{2}$ の 基本波より発生させたアト秒パルスの各CEP(相対值)に おけるスペクトルを示している。CEP変化に対する依存 性によって，このスペクトルは三つのエネルギー領域に 分類できる。

プラトー領域の低エネルギー側 (60 eV以下)では，ア 卜秒パルス列において典型的に見られる規則正しい櫛状 のスペクトルになっており，CEPの依存性は見られな い. 次に，プラトー領域の高エネルギー領域 $(60-80 \mathrm{eV})$ では, 櫛状スペクトル構造の規則性はくずれ，複雑な形 状のスペクトルとなっている。 プラトー領域における HHGは，主として二つの異なる電子トラジェクトリが 寄与していることが知られている ${ }^{36)}$. 両者は, トンネル イオン化後, 基本波電界の 1 サイクル内に再結合する電 子トラジェクトリのことを指し，短い再結合時間 $\tau_{\mathrm{S}}$ (ト ンネルイオン化してから再結合するまでの時間)の方は ショートトラジェクトリ $\left(\tau_{\mathrm{S}}<4.08 / \omega_{0}\right)$, 長い再結合時 間 $\tau_{\mathrm{L}}\left(\tau_{\mathrm{S}}<\tau_{\mathrm{L}}<2 \pi / \omega_{0}\right)$ の方はロングトラジェクトリと呼 ばれている。この複雑なスペクトル構造は，二つのトラ ジェクトリからのHHGのスペクトル干渉として理解で きる37,38)、ロングトラジェクトリは，再結合時間が長い 分, 基本波の強度変化による位相変化を受け易く, それ がHHGの波長シフトを引き起こす。そのため, 二つの トラジェクトリからのHHGが干渉を起こすと, このよ うな複雑な構造となる。CEPを変化させると位相変化を 引き起こすことになるため, CEP依存性も現れることに なるのである.

カットオフエネルギー領域では，両者は一つのトラ ジェクトリに収れんする。そのため，本スペクトルにお いてもカットオフエネルギー領域 (80 eV以上)では複雑 な構造は消失する。その代わりに本領域では, 基本波パ ルスのピーク強度近傍の隣り合うハーフサイクルからの HHGがスペクトル干渉する ${ }^{39)}$. 数サイクルパルスの場 合, CEPによって, 隣り合うハーフサイクルの電界強度 の差が大きいため, パルスの包絡線ピークと電界ピーク が一致するコサイン型パルスの場合, カットオフエネル ギー領域では, 一つのハーフサイクルからのHHGのみ が支配的になる。その結果，スペクトルはコンティ ニュームとなり，アト秒パルスは単一化される。そこか らCEPをス/2だけずらしたサイン型パルスの場合は，二 つのハーフサイクルからのHHGが同程度寄与するため, それがスペクトル干渉した結果, 櫛状のスペクトルが現 れることになる。電界の反転対称性から, CEPの $\pi$ の周 期性を持つ. Fig. 1 において, カットオフエネルギー領 域の最も高いエネルギー領域である約 $95 \mathrm{eV}$ 以上に着目 すると, $\mathrm{CEP} か ゙ \phi=\phi_{0}+0$ の時, コンティニュームに比較 的近いスペクトル構造をとることから, 凡そコサイン型 パルスに対応していると考えられる。一方， 80-95 eVの 領域では，櫛状スペクトルが見られる。従って，数サイ
クルパル励起では，最も高いエネルギー領域以外は単一 化されず，数本のパルス列になっていることが示唆され る。そのため, 数サイクルパルスを用いた振幅ゲート法 では，単一アト秒パルスを切り出すためには，CEPをコ サイン型に安定化させ，最も高いエネルギー領域におけ るコンティニューム部分を金属フィルタもしくは反射帯 域が限定されたミラーによって取り出すことが必要不可 欠である。

\section{4. サブ50アト秒コンティニュームの発生}

\section{1 準モノサイクルパルス発生}

本実験は, $20 \mathrm{fs} ハ ゚ ル ス$ 幅, $3 \mathrm{~mJ}$ パルスエネル ギー3 kHz繰返し周波数を有するCEP安定化チタンサ ファイアチャープパルス増幅システムを用いた。レー ザーからの出力を圧力約 1 気圧の Neガスを注入している 中空ファイバ(長さ $1 \mathrm{~m}$, 内径 $400 \mu \mathrm{m}$ )に集光し, 自己位 相変調効果によりスペクトル広带域化を行った。波 長400 nmから1000 nmの帯域600 nmに反射帯域並びに群 速度分散制御可能帯域を有する超広帯域チャープミラー 対で分散補償し，パルス圧縮をした結果，800 nm帯に おけるバンド幅 $139 \mathrm{~nm}$ ，パルス幅 $4.1 \mathrm{fs}$ ，パルスエネル ギー1 mJを有する1.6サイクルの準モノサイクルパルス の発生に成功した (Fig. 2(a)，(b)).

出力光における $\mathrm{CEP}$ (相対值) の $\mathrm{f}-2 \mathrm{f}$ 干渉計測結果を Fig. 2 (c) に示す。 4.5時間の計測に渡ってCEPは，極めて 安定化しており, シングルショット計測で標準偏差 は139 mradである。本システムでは，発振器のCEP安定 化は，フィードフォーワード方式を用いている ${ }^{40)}$.

$4.270 \mathrm{eV}$ 帯域アト秒コンティニューム発生

上記のCEP安定化準モノサイクルパルスを，長
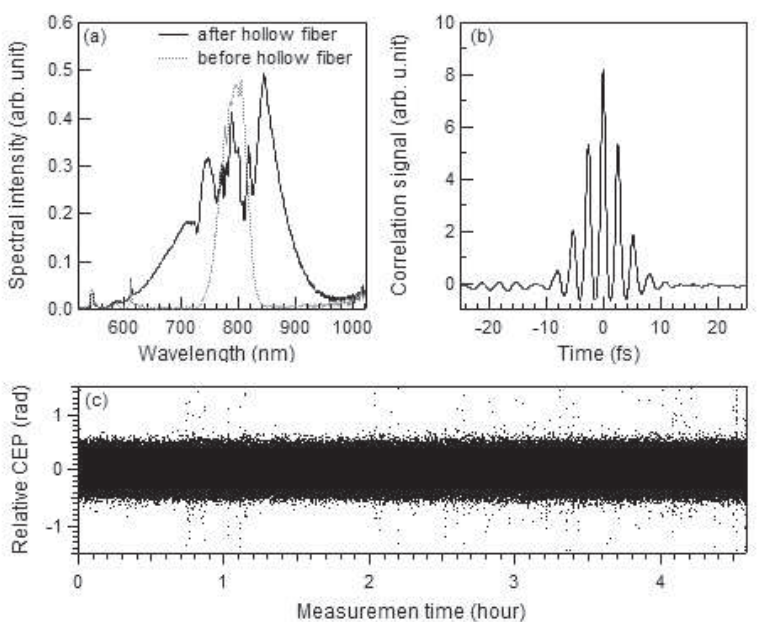

Fig. 2 Characterization of the near-infrared sub-two cycle pulse. The spectra before (dotted) and after (solid) a hollow fiber are shown, respectively (a). We also measured an interferometric autocorrelation trace (b). The CEP stability of the amplified pulses measured with a single-shot f-to- $2 \mathrm{f}$ interferometer during 4.5-hour measurement was estimated to be 139 mrad. 
さ1 $\mathrm{mm}$ のeガスセルに集光させることによりアト秒パ ルスを発生させた。焦点距離100 mmという比較的短焦 点の球面鏡を用いて集光させることにより, ピーク強 度3 $\times 10^{15} \mathrm{~W} / \mathrm{cm}^{2}$ まで集光させ，カットオフエネルギー の高エネルギー化を図った。また，基本波の光路には， 厚み $250 \mu \mathrm{m}$ 及び $480 \mu \mathrm{m}$ の水晶板, そして厚み $140 \mu \mathrm{m}$ の BBO結晶を組み合わせたDOG法用光学素子を配置して いる ${ }^{29,30)}$.

発生したアト秒パルスは, トロイダルミラーにより いったん集光され，基本波カットのためのZrフィル夕を 通過し, 平面結像型スペクトログラフに導かれる. 検出 には，マイクロチャネルプレートとCCDカメラの組み 合わせを用いた。

Fig. 3 に，準モノサイクルパルスとDOG法を組み合わ せて発生させたアト秒パルスの典型的なスペクトルを示 す。アト秒パルス列に特徵的な櫛状スペクトルではな く，コンティニュームであることがわかる，スペクトル

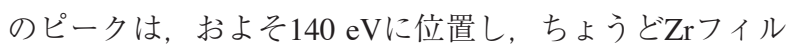
夕の最大透過波長エネルギー領域に一致している。低エ ネルギー側は, $\mathrm{Zr}$ フィルタによりフィルタリングされて いる.コンティニュームの半值全幅は, およそ70 eVに 到達し, 10パーセント強度比のエッジ部分の幅は $100 \mathrm{eV}$ を超える。この帯域幅は, フーリエ変換限界パルスを仮 定した場合には，32 asのパルス幅に相当する。このよ うに，準モノサイクルパルスとDOG法を組み合わせる
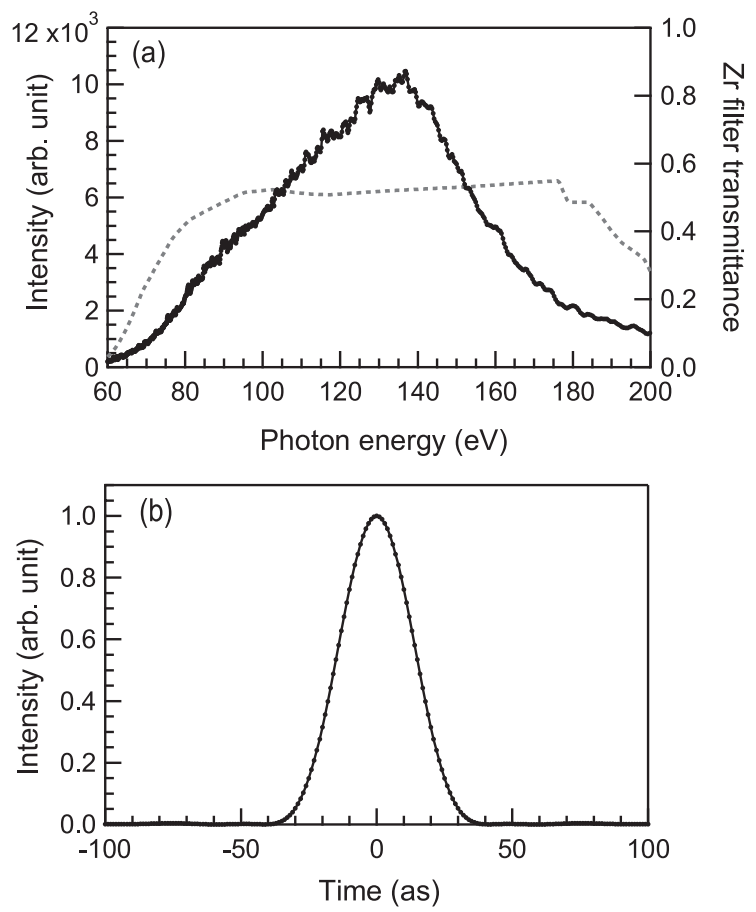

Fig. 3 Spatially-integrated attosecond supercontinuum spectrum of generated by the combination of the amplitude gating and the DOG schemes (a) and its pulse shape obtained by assuming a Fourier-transform limited pulse (b). In the low energy side of the spectrum, the detection was limited by the absorption of the $\mathrm{Zr}$ filter. The dotted curve in (a) represents the transmittance of the $\mathrm{Zr}$ filter, which corresponds to the right axis.
ことによって，サブ50 asのパルス幅をサポートするコ ンティニュームが比較的低エネルギー領域で実現でき る。これは, DOG法により，アト秒パルスの発生がほ ぼ半サイクルに限定されることによって，プラトー領域 の成分もコンティニュームとして寄与することができる ためである。

\section{3 アト秒コンティニュームのCEP依存性}

ここでは，計測されたアト秒コンティニュームが単一 アト秒パルスであることを董付けるため，スペクトルの $\mathrm{CEP}$ (相対值)依存性を計測した(Fig. 4). CEPを変化させ ることは, 基本波のピーク電界を変化させることに対応 するため，アト秒コンティニュームのエネルギー分布が CEPに依存して変化していく，その結果，このようなス ペクトルの周期的変化を引き起こすのである。また, DOG法における二色ゲートの効果により，基本波は反 転対称性を失い，非対称な電界になっている。そのた め, アト秒コンティニュームの変化はCEPの $2 \pi$ の周期 性を有している ${ }^{29)}$ 。本計測では，2時間に渡って12 $\pi$ の 周期性を明瞭に確認することができている。このこと は，CEP制御性が長時間に渡って安定であることを裏付 けている。

Fig. 5 に，上記の計測と，準モノサイクルパルスのみ の振幅ゲート法によって発生したアト秒コンティニュー ムのCEP依存性を比較した結果を示す。準モノサイクル パルス化により，振幅ゲートがよくきいていることか ら，コンティニューム成分が主のスペクトル構造になっ ていることがわかる、CEP変化による周期性は，電界が 反転対称性を有していることから， $\pi$ の周期性を示して いる，両者を比較すると，DOG法を組み合わせた結果 は(Fig. 5(b))，すべてのCEPに渡ってシングルピークの コンティニュームになっているのに対して，振幅ゲート のみの結果は(Fig. 5(a)), すべてのCEPに渡りダブル ピークとなっていることがわかる。これは，二つのハー フサイクルから発生するアト秒パルス列が干渉している ことを示しており，単一アト秒パルスとするためには, およそ120 eV以上の成分のみをフィルタリングする必要 がある。そのため, 帯域幅は狭まり最短アト秒パルス発 生には不利となる

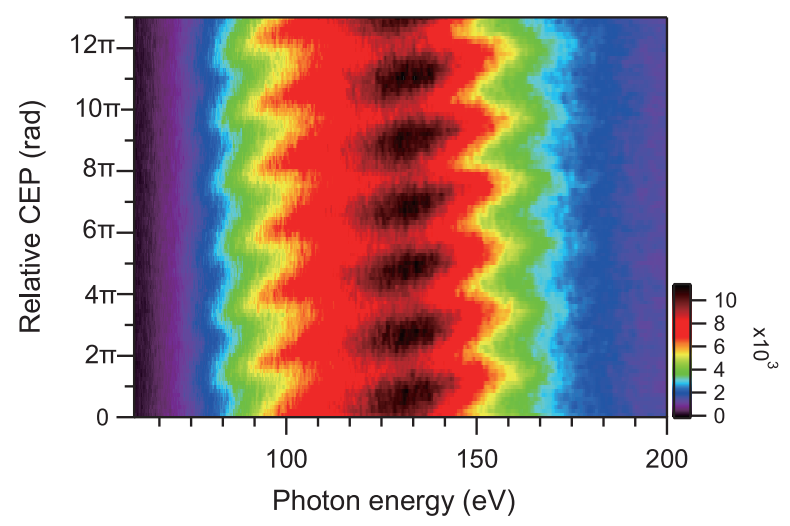

Fig. 4 CEP variation of the attosecond supercontinuum spectrum during 2-hour measurement. 


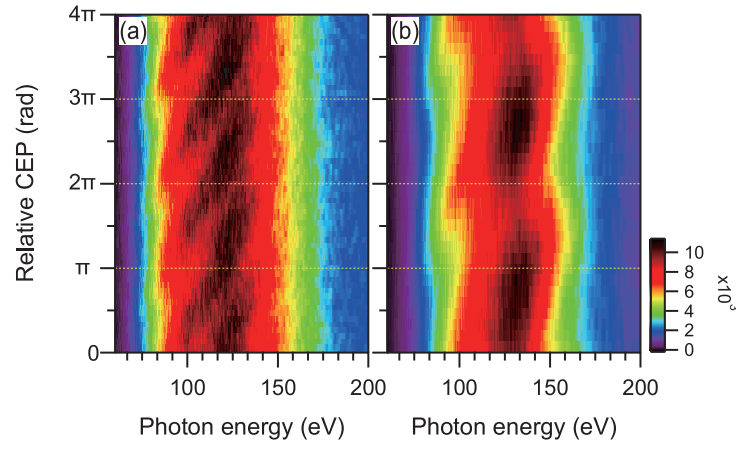

Fig. 5 CEP variation of the supercontinuum spectra generated by the amplitude gating only (a) and its combination with the DOG scheme (b). The $\pi$ and $2 \pi$ periodicities are clearly shown, respectively.

これまでの時間幅まで評価した最短の単一アト秒パルス 発生は, 67 asであり ${ }^{7)}$, スペクトル帯域幅は, 半值全幅で 凡そ40 eVである.今回の結果は, それを2倍近く上回る 帯域幅のコンティニュームを発生することに成功している。

\section{5. “水の空”領域アト秒コンティニューム発生}

本章では, DOG法で発生した“水の空” 領域のアト秒 コンティニューム発生について紹介する ${ }^{41)}$ 。“水の空”領 域とは, 波長2.3-4.4 nmの軟X線波長域を指し, この波 長領域は，生体細胞の主成分である水には透明である一 方炭素に対しては不透明となる。従って, “水の空”領域 光源は, 生体細胞の計測に適した光源として期待されて おり，アト秒パルス発生の高エネルギー化のベンチマー ク的領域になっている ${ }^{10,11)}$. Fig. 6 に, $800 \mathrm{~nm}$ 帯の基本 波を短焦点凹面鏡 $(f=100)$ で十分に集光し, DOG法を用
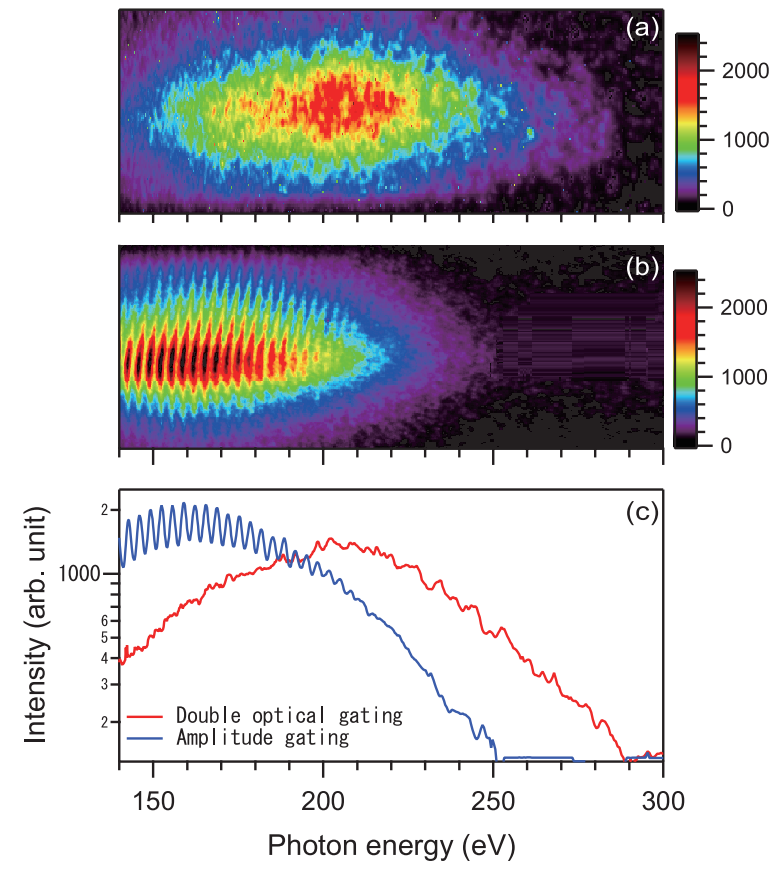

Fig. 6 High-harmonic spectral distribution with (a) DOG and the amplitude gating (b). Both are measured with carbon filter. Comparison of averaged line spectra in (a) and (b) is shown in (c).
いることで発生させた半值全幅 $100 \mathrm{eV} に$ 達するアト秒コ ンティニュームのスペクトルを示す。媒質には, 希ガス の中ではイオン化エネルギーが最も高く, カットオフエ ネルギーの高エネルギー化が期待できるHeガスを用い た。カーボンのフィルタを透過させることによ り，290 eVに位置する炭素のK吸収端が明瞭に観察され る(Fig. 6(c))。基本波のパルスエネルギーは，わず か250 $\mu \mathrm{J}$ であり, “水の空” 領域アト秒パルス発生として は世界最小のパルスエネルギーである。本スペクトルの 帯域幅からフーリエ限界パルスを仮定すると，そのパル ス幅は，時間の原子単位である 24 asよりも短い約 20 as と見積もられ，極限的に短い単一アト秒パルス発生を示 唆している。

\section{6. まとめ}

本稿では, 単一アト秒パルス発生の研究の最前線につ いて解説し, その一つとして, 我々の1.6サイクル準モ ノサイクルパルスやDOG法を組み合わせた単一アト秒 パルス発生の取り組みについて紹介した。 今後, 赤外域 基本波励起による高エネルギー単一アト秒パルスも含め て, 我々が発生させたような $100 \mathrm{eV}$ クスの超広帯域単 一アト秒パルスの時間幅を評価することが研究ターゲッ トとなる。このクラスのアト秒パルスに対して，通常時 間幅評価に用いられているアト秒ストリーク法が適用で きるかどうかは現時点では定かではない。サブ50 asパ ルスの世界は，発生と共に計測手法の革新も必要となる であろう ${ }^{42)}$.

謝 辞

本稿で紹介した研究は，東洋大学 中野秀俊教授，弘 前大学 花田 修賢准教授，小川 達也氏，NTT物性科学基 礎研究所 寒川 哲臣所長, 石澤 淳主任研究員の協力の下 行われました。ここに深く感謝申し上げます。また，本研 究の一部は, JSPS科研費 $(23310086,25706027,16 \mathrm{H} 02120)$ の助成を受けて行われました。

\section{参考文献}

1) M. Hentschel, R. Kienberger, Ch. Spielmann, G. A. Reider, N Milosevic, T. Brabec, P. Corkum, U. Heinzmann, M. Drescher, and F. Krausz: Nature 414 (2001) 509.

2) E. Goulielmakis, Z.-H. Loh, A. Wirth, R. Santra, N. Rohringer, V. S. Yakovlev, S. Zherebtsov, T. Pfeifer, A. M. Azzeer, M. F. Kling, et al:: Nature 466 (2010) 739.

3) T. Okino, Y. Furukawa, Y. Nabekawa, S. Miyabe, A. A. Eilanlou, E. J. Takahashi, K. Yamanouchi, and K. Midorikawa: Sci. Adv. 1 (2015) e1500356.

4) M. Schultze, E. M. Bothschafter, A. Sommer, S. Holzner, W. Schweinberger, M. Fiess, M. Hofstetter, R. Kienberger, V. Apalkov, V. S. Yakovlev, et al:: Nature 493 (2013) 75.

5) S. Neppl, R. Ernstorfer, A. L. Cavalieri, C. Lemell, G. Wachter, E. Magerl, E. M. Bothschafter, M. Jobst, M. Hofstetter, U. Kleineberg, et al.: Nature 517 (2015) 342.

6) F. Calegari, D. Ayuso, A. Trabattoni, L. Belshaw, S. De Camillis, S. Anumula, F. Frassetto, L. Poletto, A. Palacios, P. Decleva, et al.: Science 346 (2014) 336. 
7) K. Zhao, Q. Zhang, M. Chini, Y. Wu, X. Wang, and Z. Chang: Opt. Lett. 37 (2012) 3819.

8) E. Goulielmakis, M. Schultze, M. Hofstetter, V. S. Yakovlev, J. Gagnon, M. Uiberacker, A. L. Aquila, E. M. Gullikson, D. T. Attwood, R. Kienberger, et al.: Science 320 (2008) 1614.

9) T. Popmintchev, M.-C. Chen, D. Popmintchev, P. Arpin, S. Brown, S. Ališauskas, G. Andriukaitis, T. Balčiunas, O. D. Mücke, A. Pugzlys, et al.: Science 336 (2012) 1287.

10) N. Ishii, K. Kaneshima, K. Kitano, T. Kanai, S. Watanabe, and J. Itatani: Nat. Commun. 5 (2014) 3331.

11) S. M. Teichmann, F. Silva, S. L. Cousin, M. Hemmer, and J. Biegert: Nat. Commun. 7 (2016) 11493

12) E. J. Takahashi, P. Lan, O. D. Mücke, Y. Nabekawa, and K. Midorikawa: Nat. Commun. 4 (2013) 2691.

13) F. Ferrari, F. Calegari, M. Lucchini, C. Vozzi, S. Stagira, G. Sansone, and M. Nisoli: Nat. Photon. 4 (2010) 875

14) M. Krebs, S. Hädrich, S. Demmler, J. Rothhardt, A. Zaïr, L. Chipperfield, J. Limpert, and A. Tünnermann: Nat. Photon. 7 (2013) 555.

15) G. Sansone, L. Poletto, and M. Nisoli: Nat. Photon. 5 (2011) 655.

16) M. Chini, K. Zhao, and Z. Chang: Nat. Photon 8 (2014) 178.

17) P. Antoine, A. L' Huillier, and M. Lewenstein: Phys. Rev. Lett. 77 (1996) 1234

18) T. Brabec and R. Krausz: Rev. Mod. Phys. 72 (2000) 545.

19) P. B. Corkum and F. Krausz: Nat. Phys. 3 (2007) 381

20) P. B. Corkum: Phys. Rev. Lett. 71 (1993) 1994.

21) M. Lewenstein, Ph. Balcou, M. Yu. Ivanov, A. L'Huillier, and P. B. Corkum: Phys. Rev. A 49 (1994) 2117.

22) R. Kienberger, E. Goulielmakis, M. Uiberacker, A. Baltuska, V. Yakovlev, F. Bammer, A. Scrinzi, Th. Westerwalbesloh, U. Kleinberg, U. Heinzmann, et al.: Nature 427 (2004) 817.

23) N. Saito, N. Ishii, T. Kanai, S. Watanabe, and J. Itatani: Sci. Rep. 6 (2016) 35594.

24) Y. Oishi, M. Kaku, A. Suda, F. Kannari, and K. Midorikawa: Opt. Express 14 (2006) 7230.

25) S.-W. Huang, G. Cirmi, J. Moses, K.-H. Hong, S. Bhardwaj, J. R. Birge, L.-J. Chen, E. Li, B. J. Eggleton, G. Cerullo, et al.: Nat. Photon. 5 (2011) 475.

26) L. E. Chipperfield, J. S. Robinson, J. W. G. Tisch, and J. P.
Marangos: Phys. Rev. Lett. 102 (2009) 063003.

27) P. B. Corkum, N. H. Burnett, and M. Y. Ivanov: Opt. Lett. 19 (1994) 1870.

28) G. Sansone, E. Benedetti, F. Calegari, C. Vozzi, L. Avaldi, R. Flammini, L. Poletto, P. Villoresi, C. Altucci, R. Velotta, et al.: Science 314 (2006) 443.

29) H. Mashiko, S. Gilbertson, C. Li, S. D. Khan, M. M. Shakya, E. Moon, and Z. Chang: Phys. Rev. Lett. 100 (2008) 103906

30) X. Feng, S. Gilbertson, H. Mashiko, H. Wang, S. D. Khan, M. Chini, Y. Wu, K. Zhao, and Z. Chang: Phys. Rev. Lett. 103 (2009) 183901.

31) T. Sekikawa, A. Kosuge, T. Kanai, and S. Watanabe: Nature 432 (2004) 605.

32) M. J. Abel, T. Pfeifer, P. M. Nagel, W. Boutu, M. J. Bell, C. P. Steiner, D. M. Neumark, and S. R. Leone: Chem. Phys. 366 (2009) 9.

33) K. T. Kim, C. Zhang, T. Ruchon, J.-F. Hergott, T. Auguste, D. M Villeneuve, P. B. Corkum, and F. Quéré: Nat. Photon. 7 (2013) 651

34) J. A. Wheeler, A. Borot, S. Monchocé, H. Vincenti, A. Ricci, A. Malvache, R. Lopez-Martens, C. Zhang, G. G. Brown, K. T. Kim, et al.: Nat. Photon. 6 (2012) 829.

35) H. Vincenti and F. Quéré: Phys. Rev. Lett. 108 (2012) 113904.

36) C. Kan, C. E. Capjack, R. Rankin, and N. H. Burnett: Phys. Rev. A 52 (1995) R4336.

37) D. G. Lee, H. J. Shin, Y. H. Cha, K. H. Hong, J.-H. Kim, and C. H. Nam: Phys. Rev. A 63 (2001) 021801.

38) G. Sansone, C. Vozzi, S. Stagira, M. Pascolini, L. Poletto, P. Villoresi, G. Tondello, S. De Silvestri, and M. Nisoli: Phys. Rev. Lett. 92 (2004) 113904

39) A. Baltuška, Th. Udem, M. Uiberacker, M. Hentschel, E. Goulielmakis, Ch. Gohle, R. Holzwarth, V. S.Yakovlev, A. Scrinzi, T. W. Hänsch, et al.: Nature 421 (2003) 611.

40) S. Koke, C. Grebing, H. Frei, A. Anderson, A. Assion, and G. Steinmeyer: Nat. Photon. 4 (2010) 462.

41) H. Mashiko, K. Oguri, and T. Sogawa: Appl. Phys. Lett. 102 (2013) 171111

42) C. Zhang, G. G. Brown, K. T. Kim, D. M. Villeneuve, and P. B. Corkum: Sci. Rep. 6 (2016) 26771. 